\title{
Factors associated with suicide ideation of healthcare university students
}

\author{
Fatores associados à ideação suicida de universitários da área da saúde \\ Factores relacionados a la ideación suicida de universitarios de la área de salud
}

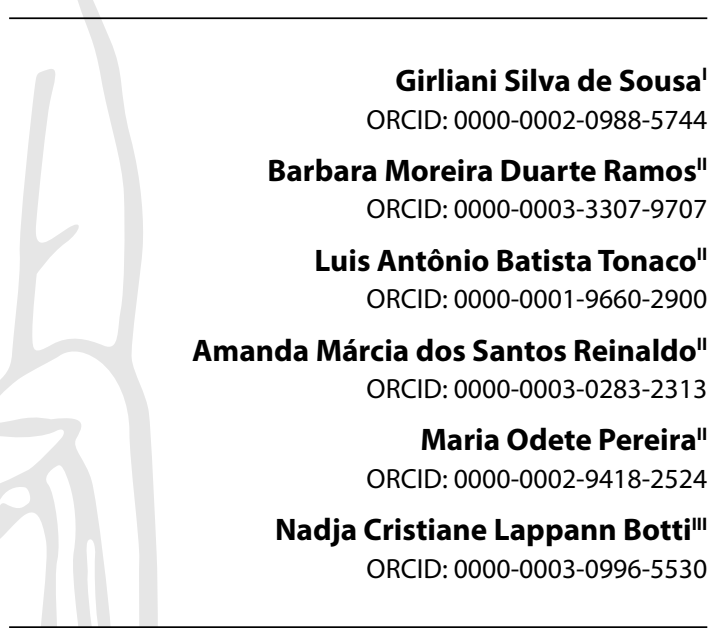

'Universidade Federal de São Paulo. São Paulo, São Paulo, Brazil. "Universidade Federal de Minas Gerais. Belo Horizonte, Minas Gerais, Brazil. "'Universidade Federal São João Del Rei. São João Del-Rei, Minas Gerais, Brazil.

How to cite this article: Sousa GS, Ramos BMD, Tonaco LAB, Reinaldo MAS, Pereira MO, Botti NCL. Factors associated with suicide ideation of healthcare university students. Rev Bras Enferm. 2022;75(Suppl 3):e20200982. https://doi.org/10.1590/0034-7167-2020-0982

Corresponding author:

Girliani Silva de Sousa E-mail: girlianis@gmail.com

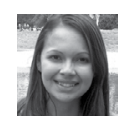

EDITOR IN CHIEF: Dulce Barbosa ASSOCIATE EDITOR: Antonio José de Almeida Filho

\section{ABSTRACT}

Ojectives: to analyze the factors associated with suicidal ideation in students from healthcare graduation courses. Methods: quantitative, cross-sectional study, with 251 students from the courses of radiology, speech-language therapy, medicine, nutrition, health service management, and nursing, from a federal higher education institution in the Southeast of Brazil. Data were collected from August to October 2019, using an electronic questionnaire. Results: the prevalence of suicidal ideation among participants was $26.33 \%$. In the final logistic regression model, only depressive symptoms were associated with suicidal ideation. Having symptoms of depression increased the chances of suicidal ideation 2.6 times. Conclusion: the high prevalence of suicidal ideation and its associated factors constitutes a situational diagnosis that demands the elaboration of public and institutional policies, focused on the promotion and attention to the mental health of the students.

Descriptors: Suicide; Suicide Attempt; Suicidal Ideation; Students; Education Higher.

\section{RESUMO}

Objetivos: analisar os fatores associados à ideação suicida de estudantes de cursos de graduação da área da saúde. Métodos: estudo quantitativo, transversal, com 251 alunos dos cursos de Radiologia, Fonoaudiologia, Medicina, Nutrição, Gestão em Serviços de Saúde e Enfermagem de uma instituição federal de Ensino Superior no Sudeste brasileiro. Os dados foram coletados no período de agosto a outubro de 2019 , por meio de questionário eletrônico. Resultados: a prevalência de ideação suicida entre os participantes foi de $26,33 \%$. No modelo de regressão logística final, apenas sintomas depressivos foram associados à ideação suicida. Ter sintomas depressivos aumentou em 2,6 as chances de apresentar ideação suicida. Conclusão: a alta prevalência da ideação suicida e seus fatores associados constituem um diagnóstico situacional que demanda a elaboração de políticas públicas e institucionais, enfocando a promoção e a atenção à saúde mental dos estudantes.

Descritores: Suicídio; Tentativa de Suicídio; Ideação Suicida; Estudantes; Educação Superior.

\section{RESUMEN}

Objetivos: Analizar los factores relacionados a la ideación suicida de estudiantes de cursos de grado de la área de salud. Métodos: Estudio cuantitativo, transversal, con 251 alumnos de los cursos de Radiología, Fonoaudiología, Medicina, Nutrición, Gestión en Servicios de Salud y Enfermería de una institución federal de Educación Superior en el Sudeste brasileño. Los datos fueron recolectados en el período de agosto a octubre de 2019, por medio de encuesta electrónica. Resultados: La prevalencia de ideación suicida entre los participantes fue de 26,33\%. En el modelo de regresión logística final, sólo síntomas depresivos fueron relacionados a la ideación suicida. Tener síntomas depresivos aumentó en 2,6 las chances de presentar ideación suicida. Conclusión: La alta prevalencia de la ideación suicida y sus factores relacionados constituyen un diagnóstico situacional que demanda la elaboración de políticas públicas e institucionales, enfocando la promoción y la atención a la salud mental de los estudiantes. Descriptores: Suicidio; Tentativa de Suicidio; Ideación Suicida; Estudiantes; Educación Superior. 


\section{INTRODUCTION}

Suicide is recognized as a worldwide public health problem. Nearly $79 \%$ of deaths by suicide take place in low and medium income countries ${ }^{(1-2)}$. Regarding the age group, suicide is the second most common cause of death in people from 15 to 29 years old ${ }^{(1)}$. In Brazil, it is the fourth main cause of death in this population ${ }^{(3)}$.

From 2011 to 2019, young Brazilians, from 15 to 29 years old - the age group of university students - represented $34 \%$ of the cases of suicide in the country. The most common way of executing the act was through the use of poison, which happened in $50.4 \%$ of cases, followed by the use of sharp objects $(17.8 \%)^{(4)}$.

Suicidal behavior, usually, involves thoughts, attitudes, planning, and the attempt itself. Suicidal ideation is the active or passive verbal manifestation of the desire to die. Its intensity may or may not culminate in the planning and attempt of suicide, which in turn is the act of intentionally causing one's own death ${ }^{(5-6)}$.

The suicidal behavior, as well as other types of psychic disease, manifests in the beginning of adult life, the same period of ingress in higher education. Therefore, the risk for suicide in students in the health field is a cause for concern around the world, due to the high rates of prevalence of suicidal ideation ${ }^{(7-10)}$. The data on this prevalence is worrisome because, the greater the intensity of the suicidal ideation, the lower the academic performance, and the higher the chances of abandoning the course ${ }^{(10)}$. Furthermore, suicidal ideation is believed to have repercussions all over the life of the student, directly reducing their quality of life.

The university environment is also an environment where many intense changes in the life of young people take place. Thus, it can trigger crises and make them vulnerable to suicide. In addition, in this period, the student is experiencing a new routine, with demands and responsibilities that may culminate in difficulties adapting and confronting the circumstances that involve the teaching institution, not to mention the development of cognitive and behavioral abilities that is required from them ${ }^{(11)}$.

As a result, the mental health of the students from the field of health deserve special attention, since they need to learn to deal with stressors that permeate the experiences they are going to go through during their formation, such as suffering and death ${ }^{(12)}$.

The increase in suicidal ideation in university students from the field of health has been shown in literature. It is a worrying reality and justifies the need for public mental health policies targeted at this audience. The student assistance programs must face the challenge of organizing and planning the attention for the students with suicidal ideation, especially those who have frail social support and few options regarding how to deal with conflicts and resolve them.

Based on the above, this study believes that identifying factors associated with suicide - socioeconomic data, history of suicide and suicide attempt in family and friends, and the presence of depressive symptoms, such as self-mutilation, suicide attempts, and the use of psychoactive drugs - is an assertive strategy to raise awareness about the theme, which is still neglected in Brazil. Consequently, the relevance of this study is in the fact that it brings to light factors associated with suicidal behavior, to subsidize the elaboration of actions in higher education institutions that effectively embrace and provide adequate treatment to university students with suicidal ideation. This care is supposed to be shared between family, State, and the civil society as a whole.

\section{OBJECTIVE}

To analyze the factors associated with the suicidal ideation of students from healthcare graduation courses.

\section{METHODS}

\section{Ethical aspects}

This study was approved by the Research Ethics Committee from a higher education institution. Alphanumeric codes were used to identify the participants and the materials collected. All recommendations and ethical measures recommended by Resolution 466/12 from the National Council of Health were respected. All participants signed the Free and Informed Consent Form (FICF) using a digital signature.

\section{Design, period, and place of study}

Quantitative, cross-sectional, descriptive study, guided by the instrument Strengthening the Reporting of Observational Studies in Epidemiology (STROBE). The federal higher education institution chosen as a setting for this study is in the state of Minas Gerais. During data collection, from August to October 2019, it offered the following courses from the health field: nursing, speech-language therapy, health service management, medicine, nutrition, and radiology technology. This institution was chosen due to the growing number of suicides in the campus where health courses are located in the university.

\section{Population; criteria of inclusion and exclusion}

The population included 1087 undergraduates. To calculate the sample, a level of confidence of $95 \%$ was considered, with a maximum error of $5 \%$ and a hypothesized prevalence of $9.9 \%{ }^{(8)}$ of suicidal ideation. That led to a sample size of 260 students. The selection was carried out by convenience.

The inclusion criteria were: 18 years old or older students, enrolled in one of the courses selected for data collection, who signed the FICF and answered the questionnaire in its entirety. Were excluded: students who were not taking part in university activities due to family/health reasons, those who were in international exchange programs, and those who did not answer the questionnaire in its entirety. The questionnaire was answered by 260 students, but 9 questionnaires were discarded, as there were unanswered questions in them. The total, as a result, was of 251 valid instruments.

\section{Study protocol}

The link for the electronic questionnaire was made available to all students from the course who would participate through their class representatives. The data collection was carried out from August to October 2019, using a semi-structured instrument, a form elaborated using the Google Forms tool. 
The instrument was divided in sessions: general characterization of participants (sex, skin color, age group, sexual orientation, marital status, student financial aid, origin of income, mean monthly income, housing, religion, period, and course); questions related to suicide in the social environment (suicides and suicide attempts in relatives or friends); Major Depression Inventory (MDI), which is based on the Diagnostic and Statistical Manual of Mental Disorders (DSM-V) and the International Classification of Diseases (ICD-10) ${ }^{(13)}$, in addition to the test Alcohol, Smoking and Substance Involvement Screening Test (ASSIST) ${ }^{(14)}$.

The research was announced to all regular students in the courses that participated by the Communication Department from the nursing and medicine schools, via the websites of the courses, the personal email of students, and social media (WhatsApp, Facebook, and Instagram).

The variable selected as the outcome was the presence or absence of suicidal ideation, according to the question: "Did you think about killing yourself in the last 30 days?"

\section{Analysis of results and statistics}

The data found was stored in Microsoft Excel, in a spreadsheet generated automatically in the application Google Forms. Later, they were compared using the software Epi Info 3.5 and analyzed using the software Stata 13.1.

For the significance test of the study, a gross model was used for the analysis of the association of the variables with the outcome, with a significance level of 0.05 and a confidence interval $(\mathrm{Cl})$ of $95 \%$. For the multivariate analysis, Poisson's regression model was applied. Variables with $\mathrm{p} \leq 0.20$ in non-adjusted analysis were tested, and those that presented $p<0.05$, with a $95 \% \mathrm{Cl}$, were kept.

\section{RESULTS}

The prevalence of suicidal ideation in the university students from the field of health was $26.33 \%(n=66)$, and $14.34 \%$ had attempted suicide at some point in their lives $(n=34)$. Table 1 shows the associations of demographic, socioeconomic, and academic variables with the presence of suicidal ideation. Regarding sex, $84.80 \%(n=213)$ of participants were women, while $16.20 \%(n=38)$ were men. It stands out that $41.07 \%(n=23)$ of participants who declared to be homosexual expressed suicidal ideation, as opposed to $21.99 \%(n=42)$ of those who declared to be heterosexual.

The variables sex, marital status and monthly income had a significant association with suicidal ideation. However, the variables sex, skin color, age group, sexual orientation, housing, course, and period of the course in which the student was did not have a significant association with the suicidal ideation. Although no significant association was found, it stands out that $39.29 \%(n=11)$ of those who declared having black skin had suicidal ideation.

Table 2 shows the association of a history of suicide and suicide attempts in the family/friends $(p=0.05)$ with suicidal ideation in the participants.

Table 3 shows that depressive symptoms, previous suicide attempts and self-mutilation had a significant association with suicidal ideation.

Table 4 shows that, after the multivariate Poisson regression, the depressive symptoms continued to be in association with the suicidal ideation. Having symptoms of depression increased the chances of suicidal ideation 2.6 times.

When the variable previous suicide attempt was controlled for after the logistic regression, the unit depressive symptoms $(p=0.000$, IC: $1.70-0.44)$ still showed an association with suicidal ideation.

Table 1 - Association of demographic, socioeconomic, and academic variables of the university students with the presence of suicidal ideation, Minas Gerais, Brazil, 2020

\begin{tabular}{|c|c|c|c|c|c|c|}
\hline \multirow{2}{*}{ Variables } & \multicolumn{2}{|c|}{ Yes } & \multicolumn{2}{|c|}{ No } & \multirow{2}{*}{ PR (Cl-95\%) } & \multirow{2}{*}{$p$ value* } \\
\hline & $\mathbf{n}$ & (\%) & $\mathbf{n}$ & (\%) & & \\
\hline Sex & & & & & & $<0.001$ \\
\hline Female & 59 & 28.10 & 151 & 71.90 & $1.70(1.15-2.53)$ & \\
\hline Male & 06 & 16.22 & 31 & 83.78 & - & \\
\hline Skin color & & & & & & 0.179 \\
\hline White & 34 & 23.45 & 111 & 76.55 & - & \\
\hline Brown & 19 & 27.14 & 51 & 72.86 & $0.61(0.380 .99)$ & \\
\hline Black & 11 & 39.29 & 17 & 60.71 & $0.67(03.4-1.32)$ & \\
\hline Yellow & 1 & 25.00 & 3 & 75.00 & $0.67(1.21-3.73)$ & \\
\hline Age group & & & & & & 0.712 \\
\hline Up to 20 years old & 17 & 30.91 & 38 & 69.09 & $0.97(0.62-1.54)$ & \\
\hline $21-30$ years old & 51 & 30.18 & 118 & 69.82 & $1.18(0.49-2.83)$ & \\
\hline $31-40$ years old & 4 & 36.36 & 7 & 63.64 & $1.62(0.81-3.23)$ & \\
\hline$>41$ years old & 6 & 50.00 & 6 & 50.00 & & \\
\hline Sexual orientation & & & & & & 0.251 \\
\hline Heterosexual & 42 & 21.99 & 149 & 78.01 & - & \\
\hline Homosexual & 23 & 41.07 & 33 & 58.93 & & \\
\hline Marital status & & & & & - & $<0.001$ \\
\hline Single & 59 & 27.19 & 158 & 72.81 & $1.42(0.88-2.31)$ & \\
\hline Married/su & 5 & 20.00 & 20 & 80.00 & $5.35(2.17-1.32)$ & \\
\hline Divorced & 1 & 20.00 & 4 & 80.00 & & 0.179 \\
\hline \multicolumn{7}{|l|}{ Student financial aid } \\
\hline Yes & 28 & 34.15 & 54 & 65.85 & $0.74(0.48-1.13)$ & \\
\hline No & 37 & 22.42 & 128 & 77.58 & - & 0.532 \\
\hline
\end{tabular}




\begin{tabular}{|c|c|c|c|c|c|c|}
\hline \multirow{2}{*}{ Variables } & \multicolumn{2}{|c|}{ Yes } & \multicolumn{2}{|c|}{ No } & \multirow{2}{*}{ PR (Cl-95\%) } & \multirow{2}{*}{$p$ value* } \\
\hline & $\mathbf{n}$ & (\%) & $\mathbf{n}$ & (\%) & & \\
\hline \multicolumn{7}{|l|}{ Origin of the income of the student } \\
\hline The student lives on their own income & 6 & 28.57 & 15 & 71.43 & - & \\
\hline The student receives support from others & 45 & 24.46 & 139 & 75.54 & $0.99(0.52-1.89)$ & \\
\hline $\begin{array}{l}\text { The student helps supporting their home, but receives support } \\
\text { from others }\end{array}$ & 14 & 33.33 & 28 & 66.67 & $0.71(0.32-1.61)$ & \\
\hline Mean monthly income & & & & & & 0.041 \\
\hline Up to $1 \mathrm{MW}$ & 7 & 28.00 & 18 & 72.00 & - & \\
\hline $1-3 \mathrm{MW}$ & 29 & 24.17 & 91 & 75.83 & $0.75(0.39-1.45)$ & \\
\hline$>3 \mathrm{MW}$ & 41 & 40.20 & 61 & 59.80 & $1.25(0.67-2.33)$ & \\
\hline Housing & & & & & & 0.596 \\
\hline Lives alone & 1 & 11.11 & 8 & 88.89 & - & \\
\hline Has roommates & 10 & 27.78 & 26 & 72.22 & $0.62(0.25-1.54)$ & \\
\hline Relatives in general/others & 64 & 31.68 & 138 & 68.32 & $0.71(0.33-1.52)$ & \\
\hline Religion & & & & & & 0.428 \\
\hline Catholic & 22 & 24.44 & 68 & 75.56 & - & \\
\hline Protestant & 6 & 13.95 & 37 & 86.05 & $0.91(0.54-1.53)$ & \\
\hline Others & 13 & 29.55 & 31 & 70.45 & $0.57(0.30-1.10)$ & \\
\hline Does not have a religion & 24 & 34.29 & 46 & 65.71 & $0.92(0.60-1.42)$ & \\
\hline Course & & & & & & 0.441 \\
\hline Nursing & 23 & 20.72 & 88 & 79.28 & - & \\
\hline Nutrition & 16 & 35.56 & 29 & 64.44 & $0.68(0.37-1.26)$ & \\
\hline Health service management & 11 & 34.38 & 21 & 65.63 & $0.96(05.541 .72)$ & \\
\hline Medicine & 9 & 29.03 & 22 & 70.97 & $1.40(0.87-2.48)$ & \\
\hline Radiology & 3 & 30.00 & 7 & 70.00 & $0.92(0.34-2.48)$ & \\
\hline Speech-language therapy & 3 & 16.67 & 15 & 83.33 & $0.86(0.39-1.90)$ & \\
\hline Period & & & & & - & 0.141 \\
\hline 1 st to 6 th & 43 & 25.44 & 126 & 74.56 & $1.32(0.91-1.90)$ & \\
\hline 7 th to 11 th & 22 & 28.21 & 56 & 71.79 & & \\
\hline
\end{tabular}

PR: prevalence ratio; * $p$ value: Poisson's regression model; su: stable union.

Table 2 - Association of a history of suicide and suicide attempts in the family/friends of the students and the presence of suicidal ideation, Minas Gerais, Brazil, 2020

\begin{tabular}{|c|c|c|c|c|c|c|}
\hline \multirow{2}{*}{ Variables } & \multicolumn{2}{|c|}{ Yes } & \multicolumn{2}{|c|}{ No } & \multirow{2}{*}{ PR (Cl-95\%) } & \multirow{2}{*}{$p$ value* } \\
\hline & $\mathbf{n}$ & (\%) & $\mathbf{n}$ & (\%) & & \\
\hline Suicide attempt in the family/friends & & & & & & 0.051 \\
\hline Yes & 46 & 29.11 & 112 & 70.89 & & \\
\hline No & 19 & 21.35 & 70 & 78.65 & $0.69(0.48-0.99)$ & \\
\hline Suicide in the family/friends & & & & & & 0.613 \\
\hline Yes & 21 & 27.27 & 56 & 72.73 & & \\
\hline No & 44 & 25.88 & 126 & 74.12 & $0.91(0.75-1.01)$ & \\
\hline
\end{tabular}

PR: prevalence ratio; * $p$-value: Poisson's regression model.

Table 3 - Association of the use of psychoactive substances, depressive symptoms, previous suicide attempts, and self-mutilation with suicidal ideation in university students, Minas Gerais, Brazil, 2020

\begin{tabular}{|c|c|c|c|c|c|c|}
\hline \multirow{2}{*}{ Variables } & \multicolumn{2}{|c|}{ Yes } & \multicolumn{2}{|c|}{ No } & \multirow{2}{*}{ PR (Cl-95\%) } & \multirow{2}{*}{$p$ value* } \\
\hline & $\mathbf{n}$ & (\%) & $\mathbf{n}$ & (\%) & & \\
\hline Major Depression Inventory & & & & & & $<0.001$ \\
\hline Present & 59 & 36.65 & 102 & 63.35 & $0.47(0.36-0.61)$ & \\
\hline Absent & 6 & 6.98 & 80 & 93.02 & - & \\
\hline \multicolumn{7}{|l|}{ Suicide attempt } \\
\hline Yes & 20 & 55.56 & 16 & 44.44 & $0.15(0.04-0.06)$ & 0.018 \\
\hline No & 45 & 21.33 & 166 & 78.67 & - & \\
\hline \multicolumn{7}{|l|}{ Self-mutilation } \\
\hline Yes & 43 & 38.39 & 69 & 61.61 & $0.24(0.14-0.41)$ & $<0.001$ \\
\hline No & 22 & 16.30 & 113 & 83.70 & - & \\
\hline ASSIST** & & & & & & 0.173 \\
\hline Occasional use & 22 & 17.46 & 104 & 82.54 & - & \\
\hline Abusive use & 30 & 31.91 & 64 & 68.09 & $0.93(0.63-1.37)$ & \\
\hline Suspected dependence & 13 & 48.15 & 14 & 51.85 & $0.54(0.24-1.24)$ & \\
\hline
\end{tabular}

PR: prevalence ratio; * $p$-value: Poisson's regression model.

**ASSIST: Screening test for involvement with alcohol, tobacco and other substances. 
Table 4 - Poisson's multivariate regression model, adjusted for factors associated with the suicidal ideation of university student, Minas Gerais, Brazil, 2020

\begin{tabular}{lcc}
\hline Variables & PR (Cl-95\%) & p value* \\
\hline $\begin{array}{l}\text { Major Depression } \\
\text { Present } \\
\text { Absent }\end{array}$ & $2.60(1.70-3.97)$ & $<0.001$ \\
\hline PR: prevalence ratio; ${ }^{*}$ p-value: Poisson's regression model. &
\end{tabular}

\section{DISCUSSION}

The prevalence of suicidal ideation in undergraduate students of the health field was $26.33 \%$ ( $n=66$ ). This result is similar to the one found in an investigation in the Brazilian Northeast, which found $22 \%$ suicidal ideation in university students in the field of health ${ }^{(10)}$.

Similar results were found in other continents. An investigation in Ethiopia found that $23.7 \%$ of medicine students presented suicidal ideation $^{(15)}$. In China, $20.5 \%$ of medicine undergraduates reported suicidal ideation ${ }^{(9)}$. A study in Ghana found $21.3 \%$ of suicidal ideation in nursing students ${ }^{(16)}$.

This is not only the case of courses from the health field, as a study developed in 12 countries from four different cultural perspectives (Confucianist, Islamic, Anglo-Saxon, and Catholic) found that $28.8 \%$ of university students showed suicidal ideation ${ }^{(7)}$. In the United Kingdom, 31\% of university students reported suicidal ideation and, from these, $12.1 \%$ made suicide plans in the last 12 months, with $8.2 \%$ reporting that they did attempt it ${ }^{(17)}$. On the other hand, a study in six cities in Asia reported an index of $11.7 \%$ of suicidal ideation in students from many different graduation courses ${ }^{(18)}$. A Brazilian investigation with undergraduates from other fields also found lower suicidal ideation scores, with a prevalence of $9.9 \%{ }^{(8)}$. The reason for these particularities may be in the methodological design and in the instruments used, as well as in the socioeconomic differences, in the profile of the graduation courses and in their cultural aspects.

The results of the linear regression analysis indicated that depressive symptoms and previous suicide attempts were the factors that were most commonly associated with the presence of suicidal ideation. When the variable previous suicide attempt was controlled, the presence of depressive symptoms was still part of the regression model. The depression changes the attention and the concentration, having a negative effect on the ability to learn, understand, and solve academic problems ${ }^{(19)}$.

Depression in university students of courses in the health field may be related to other difficulties, including the adaptation to the university context, the distance from friends and family, financial difficulties, and the lack of identification with the course ${ }^{(11)}$. University students, in their practical activities, grow closer with disease, death, and terminal situations ${ }^{(11)}$. These are potentially related with the cognitive model of depression, in which there is pessimism in regard to the self, the world, and the future ${ }^{(11)}$.

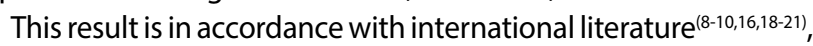
since university students with depressive symptoms are six times more likely to commit suicide ${ }^{(20)}$. An investigation with 7,108 Portuguese university students found an association of depressive symptoms (OR: 1.108) and loneliness (OR: 1.095) with suicidal ideation $^{(21)}$. A similar result was found in China, in a study with 3,257 medicine students, in which the depressive symptoms showed a direct and an indirect effect in the risk of suicide, due to the emotional regulation of self-efficacy ${ }^{(9)}$.

A Brazilian investigation with 792 students from courses in the health field found a higher prevalence of depression in female students, obese ones, and in those who did not have time for leisure ${ }^{(11)}$. A longitudinal study followed, for 12 months, 117 nursing students in São Paulo, not finding any significant increases in the levels of stress and in the depressive symptoms after the student started the course ${ }^{(22)}$. The students reported high levels of stress during the practical activities, with preoccupations related to the procedures and management of patients and difficulties to manage the academic demand, to the detriment of social, family, and personal needs ${ }^{(22-23)}$. This reality is a sign of the experience of alterations in the affective and behavioral dimensions, such as despondency, sadness, lack of energy, despair, diminution of concentration with social and occupational prejudices, and negative thoughts. These feelings often culminate in suicidal intentions, considering a stressful routine and the high hour load of some courses.

A clinical model of the suicidal behavior proposed by Mann ${ }^{(24)}$ found that people with a history of suicidal attempts had a more severe perception of depression. Other central factors were the level of suicidal ideation and despair. The results of the study reported here reiterate this model, in which the most common stressors that led to suicidal ideation were the depressive symptoms.

Depression, in the psychiatric clinic, is a mood disorder that oscillates from moderate to profound, from short to long duration, with mood alterations, loss of interest and pleasure in life, and low levels of energy ${ }^{(25)}$. Among young people, depression is usually associated with emotional and cognitive aspects, such as anxiety, loneliness, sadness, and negativity. To them, it is like their world becomes narrower, their choices more limited, and their interests and preferences less available ${ }^{(21)}$. The unsurmountable sadness becomes suicidal ideation, associated with the need they feel to put an end to a situation they cannot stand, with the felt incapacity of doing things better.

The results found corroborate the theory of the suicidal mode, by M. D. Rudd ${ }^{(26)}$, who approaches suicide from a cognitive-behavioral perspective. The theoretical base is expressed by the notion that the cognitive schemes of the suicidal mode incorporate maladaptive beliefs, which are opposed to hope. The affective schemes are characterized by a mix of negative emotions, including sadness, anxiety, anger, and guilt. The behavioral/motivational schemes are responsible for the impulse towards the suicidal act.

Suicide attempts at some point in students' lives suggest that these young people are more vulnerable to such risk. The magnitude of suicide attempts in this study was of $14.34 \%$ - a higher result than the one reported in the case of American medicine students, which showed a prevalence of $3.9 \%$ of suicide in the last year of the course ${ }^{(15)}$. An investigation in 12 countries found a prevalence of $7 \%{ }^{(7)}$. The difference may result from the inclusion of students from all periods of the course, and from differences in sample size and period when the suicide attempt took place.

Regarding suicides and attempts in the family or among friends, this variable was associated with suicidal ideation. The transmission of the suicidal behavior within the family, as a distant risk factor, is attributed to genetic factors ${ }^{(27)}$. Interpersonal relationships have a significant influence over the behavior of a 
person $^{(8,19,27)}$. Students who had relationships with relatives and friends who have attempted suicide learn this behavior as a way of solving problems, leading them to reproduce the act.

This investigation showed that self-mutilation, as a behavioral and cognitive aspect showed an association with suicidal ideation, which was not true for the final model. This ineffective mechanism happens when a person shows aggressive behavior that prejudice themselves ${ }^{(28)}$. An investigation with 408 students in two universities in the United States found that self-mutilation, is a predictor for suicidal ideation ${ }^{(28)}$. This association is explained due to the fact that self-mutilation regulates emotions. Therefore, those who mutilate themselves for years and use several methods to do so have higher levels of suicidal ideation and are more likely to attempt suicide ${ }^{(17,28-29)}$. The findings of this investigation add to literature the idea that thoughts, acts, forms, and modalities of self-mutilation, in themselves, are not sufficient to increase the likelihood of young people to attempt suicide. The evaluation of thoughts and acts of self-mutilation, however, provides a window of opportunities to intervene and mitigate the risk of developing suicidal thoughts.

The use of psychoactive drugs had no association with suicidal ideation. An investigation with university students attended in a student health service found that the use of psychotropics was a predictive factor for suicidal ideation ${ }^{(3)}$. The use of psychoactive drugs and the excessive intake of alcohol are associated with suicidal ideation in this population ${ }^{(7,10,17,19,29-30)}$. As a result, the use of psychoactive substances (PAS) should be understood as a warning sign, since it interferes in perceptions about the self, the world, and the future.

Alcohol dependence was associated with a significant increase in the probability of suicide attempts or self-mutilation, with a suicide plan or suicide attempt ${ }^{(17,19)}$. The use of PAS is motivated by the desire to reduce negative feelings, as reported in an investigation with American students, which identified the use of these substances as important mediators between loneliness and suicidal ideation $^{(29)}$. For lonely university students, the use of PAS masks negative emotions, acting as an ineffective mechanism to cope and find relief for the depressed mood. The habit of using PAS allows students to get closer to specific social groups, reducing social inhibition as they interact with their colleagues ${ }^{(7,10,31)}$.

Although the variables from sociodemographic data were not maintained in the regression model, it was found that being female, single, and having an income above three minimum wages had an indirect association with suicidal ideation. These results should be examined carefully, since the sample cannot be generalized due to the number of students who participated in this study, coupled with the significant number of women in health field courses. The prevalence of suicidal ideation was significantly higher in females, corroborating studies from Turkey, Ghana, and Ethiopia ${ }^{(16,19,32)}$.

The monthly income of the young university students in the health field is different than that from the students in other graduation courses, which partially explain the results found. Literature shows that, in contexts where the students are in lower economic levels, suicidal thoughts are from two to seven times more common (PR: 3.72) ${ }^{(8)}$. The low income was also associated with psychic suffering among university students showing the prejudicial effect of negative socioeconomic characteristics in their lives ${ }^{(10-11,33)}$.

Regarding sexual orientation, it showed no association with suicidal ideation. However, students who self-declared homosexual showed suicidal ideation more often. Investigations have also shown that this population reports suicidal ideation more frequently ${ }^{(8,34)}$. A research showed that university students from the USA, who declared to be homosexual, were three times more likely to suicide, when compared to heterosexual colleagues ${ }^{(24)}$. In this study, the variables social and family support and violence were not analyzed with the outcome. The absence of these variables interferes in the result found, since suicidal behavior is a complex phenomenon, which involves the interaction of social, cultural, psychological, and relational factors. Theoretical models on suicide and results from literature state that frail social and family support, as well as a history of violence in childhood are predictors of suicidal behavior in young people (26-29,32). $^{\text {. }}$

A study in the United Kingdom with 739 students found that having a sexual orientation that is not socially expected is associated with a history of self-mutilation, suicidal behavior, and the experience of multiple types of violence in childhood, such as mistreatment, domestic violence, physical punishment, physical and emotional abuse, and family negligence ${ }^{(17)}$. Therefore, researches are needed to explore the experiences of minority and marginalized groups, to understand and evaluate the risk of suicide in this population.

The identification of variables associated with suicidal ideation in the university context indicates the need to implant preventive programs and programs that promote mental health, to identify psychic suffering earlier and develop coping strategies that can reduce the risk of suicide.

A systematic review ${ }^{(35)}$ of programs or policies for the primary prevention of suicide in universities found that the interventions were based on instructions in the classroom and on the training of the gatekeepers, which increased the knowledge about suicide in the short term. Evidence suggests minimal long-term effects and no effect on suicidal behavior. Only one university implemented a preventive policy against suicide, restricting the access to cyanide in labs and demanding professional evaluation for students who threatened or attempted suicide, which significantly reduced suicide among students. There are no reports of policies in low-to-medium income countries.

It should be considered that the person with suicidal behavior does not always express or externalize what they feel, which is another challenge for the care of university students with suicidal ideation. Consequently, the nurse has competences that will certainly help in the identification and management of suicidal ideation: attentive listening, empathy, non-verbal signs of acceptance, respecting the other's opinion, talking honestly, showing preoccupation, and focusing on the feelings of the person ${ }^{(36)}$.

The nurse, as they provide qualified listening, have a strong potential to calm, prevent, or minimize the intensity of the symptoms. However, the scarcity of nurses in the academic environment of the current context of higher education institutions is certainly a challenge for the elaboration of programs and policies to minimize the phenomena in teaching and health institutions, strengthening the bonds and providing qualified listening. The implementation of a policy to prevent suicide is paramount, disseminating the subject further, identifying and evaluating the students at risk of suicide, and establishing a steady flow between them and the mental health care network, with a psychological and adequate psychiatric treatment for those with suicidal ideation. 


\section{Study limitations}

The method of this study is one of its limitations, since its crosssectional character does not allow for the inference of causal associations. Investigations with prospective and longitudinal methodological designs are more recommended to identify the phenomenon and to clarify what determines the transition from the suicidal ideation to the suicide attempt. Another element is the use of a question with two possibilities of response to screen for suicidal ideation. Furthermore, the sample was by convenience, formed by students from a single public university, restricting it to a single location.

\section{Contributions to the field}

The results of this study contribute to reiterate the importance of nurses in the academic field and their insertion in the implantation of programs for the embrace and psychological follow-up of university students, especially those in vulnerable situations, during their graduations in the field of health, to make it possible to prevent suicide. Higher education institutions must partner up with the mental health services to guarantee an adequate and timely treatment to these young people.

\section{CONCLUSION}

The prevalence of suicidal ideation in undergraduate students from the courses in the health field evaluated was $26.33 \%(n=66)$.

In the multivariate analysis, the associated factors were sex, marital status, monthly income, history of suicide attempts in the family and/or in friends, depressive symptoms, self-mutilation, and previous suicide attempts. In the final logistic regression model, university students with depressive symptoms showed associations with suicidal ideation.

The high prevalence of suicidal ideation and its associated factors constitute a situational diagnosis that demands the formulation and the funding of public and institutional policies, focused on the promotion and attention to the mental health of the university students.

\section{REFERENCES}

1. World Health Organization (WHO). Suicide rate estimates, crude, 15-29 and 30-49 years: estimates by country [Internet]. Geneva: WHO; c2016[cited 2020 Aug 14]. Available from: https://apps.who.int/gho/data/node.main.MHSUICIDEAGEGROUPS15293049?lang=en

2. Organização Panamericana da Saúde (OPAS). Folha informativa: suicídio [Internet]. Brasília, DF: OPAS; 2018 [cited 2020 Aug 14]. Available from: https://www.paho.org/bra/index.php?option=com_content\&view=article\&id=5671:folha-informativa-suicidio\&ltemid=839

3. Ministério da Saúde (BR). Setembro amarelo: agenda estratégica de prevenção do suicídio [Internet]. Brasília, DF; 2017 [cited 2020 Aug 14]. Available from: https://www.cvv.org.br/wp-content/uploads/2017/09/Boletim_suicidio_MS_set17.pdf

4. Ministério da Saúde (BR). Perfil epidemiológico dos casos notificados de violência autoprovocada e óbitos por suicídio entre jovens de 15 a 29 anos no Brasil, 2011 a 2018 [Internet]. Brasília, DF: MS; 2019[cited 2020 Aug 14]. Available from: https://www.saude.gov.br/images/ pdf/2019/setembro/13/BE-suic--dio-24-final.pdf

5. Durkheim E. O suicídio: estudo de sociologia. São Paulo: Martins Fontes; 2000.

6. Shneidman ES. Autopsy of a suicidal mind. Oxford: Oxford University Press; 2004.

7. Eskin M, Sun J-M, Abuidhail J, Yoshimasu K, Kujan O, Janghorbani M, et al. Suicidal behavior and psychological distress in university students: a 12-nation study. Arch Suicide Res. 2016;20(3):369-88. https://doi.org/10.1080/13811118.2015.1054055

8. Santos HGB, Marcon SR, Martinez Espinosa M, Baptista MN, Paulo PMC. Factors associated with suicidal ideation among university students. Rev Latino-Am Enfermagem. 2017;25:e2878. https://doi.org/10.1590/1518-8345.1592.2878

9. Zeng B, Zhao J, Zou L, Yang X, Zhang X, Wang W, et al. Depressive symptoms, post-traumatic stress symptoms and suicide risk among graduate students: the mediating influence of emotional regulatory self-efficacy. Psychiatry Res. 2018;264:224-30. https://doi.org/10.1016/j. psychres.2018.03.022

10. Veloso LUP, Lima CLS, Sales JCS, Monteiro CFS, Gonçalves AMS, Silva Jr FJG. Suicidal ideation among health field undergraduates: prevalence and associated factors. Rev Gaucha Enferm. 2019;40:e20180144. https://doi.org/10.1590/1983-1447.2019.20180144

11. Bresolin JZ, Dalmolin GL, Vasconcellos SJL, Barlem ELD, Andolhe R, Magnago TSBS. Depressive symptoms among healthcare undergraduate students. Rev Latino-Am Enfermagem. 2020;28:e3239. https://doi.org/10.1590/1518-8345.3210.3239

12. Graner KM, Cerqueira ATDAR. Revisão integrativa: sofrimento psíquico em estudantes universitários e fatores associados. Cienc Saude Colet. 2019;24(4):1327-46. https://doi.org/10.1590/1413-81232018244.09692017

13. Parcias S, Rosario BP, Sakae T, Monte F, Guimarães ACA, Xavier AJ. Validação da versão em português do inventário de depressão maior. J Bras Psiquiatr. 2011;60(3):164-70. https://doi.org/10.1590/S0047-20852011000300003

14. Henrique IFS, De Micheli D, Lacerda RB, Lacerda LA, Formigoni MLOS. Validação da versão brasileira do teste de triagem do envolvimento com álcool, cigarro e outras substâncias (ASSIST). Rev Assoc Med Bras. 2004;50(2):199-206. https://doi.org/10.1590/ S0104-42302004000200039

15. Asfaw H, Yigzaw N, Yohannis Z, Fekadu G, Alemayehu Y. Prevalence and associated factors of suicidal ideation and attempt among undergraduate medical students of Haramaya University, Ethiopia: a cross sectional study. PLoS One. 2020;15(8):e0236398. https://doi. org/10.1371/journal.pone.0236398 
16. Quarshie EN-B, Cheataa-Plange HV, Annor F, Asare-Doku W, Lartey JKS. Prevalence of suicidal behaviour among nursing and midwifery college students in Ghana. Nurs Open. 2019;6(3):897-906. https://doi.org/10.1002/nop2.271

17. O'Neill S, McLafferty M, Ennis E, Lapsley C, Bjourson T, Armour C, et al. Socio-demographic, mental health and childhood adversity risk factors for self-harm and suicidal behaviour in College students in Northern Ireland. J Affect Disord. 2018;239:58-65. https://doi. org/10.1016/j.jad.2018.06.006

18. Peltzer K, Yi S, Pengpid S. Suicidal behaviors and associated factors among university students in six countries in the association of Southeast Asian nations (ASEAN). Asian J Psychiatr. 2017;26:32-8. https://doi.org/10.1016/j.ajp.2017.01.019

19. Abdu Z, Hajure M, Desalegn D. Suicidal behavior and associated factors among students in Mettu University, South West Ethiopia, 2019: an institutional based cross-sectional study. Psychol Res Behav Manag. 2020;13:233-43. https://doi.org/10.2147/PRBM.S240827

20. Becker SP, Dvorsky MR, Holdaway AS, Luebbe AM. Sleep problems and suicidal behaviors in college students. J Psychiatr Res. 2018;99:122-8. https://doi.org/10.1016/j.jpsychires.2018.01.009

21. Pereira AAG, Cardoso FMS. Searching for psychological predictors of suicidal ideation in university students. Psic Teor Pesqui. 2017;33:e33420. https://dx.doi.org/10.1590/0102.3772e33420

22. Silva RM, Costa ALS, Mussi FC, Lopes VC, Batista KM, Santos OP. Health alterations in nursing students after a year from admission to the undergraduate course. Rev Esc Enferm USP. 2019;53:e03450. https://doi.org/10.1590/s1980-220x2018008103450

23. Pereira MO, Pinho PH, Cortes JM. Qualidade de vida: percepção de discentes de graduação em enfermagem. J Nurs Health. 2016;6(2):32133. https://doi.org/10.15210/jonah.v6i2.5780

24. Mann JJ, Waternaux C, Haas GL, Malone KM. Toward a clinical model of suicidal behavior in psychiatric patients. Am J Psychiatry 1999;156(2):181-9. https://doi.org/10.1176/ajp.156.2.181

25. American Psychiatric Association. Diagnostic and statistical manual of mental disorder: DSM-5. Washington, DC: APA; 2013.

26. Rudd MD. The suicidal mode: a cognitive-behavioral model of suicidality. Suicide Life Threat Behav. 2000;30(1):18-33. https://doi. org/10.1111/j.1943-278X.2000.tb01062.x

27. Cheng Q, Li H, Silenzio V, Caine ED. Suicide contagion: a systematic review of definitions and research utility. PLoS One. 2014;9(9):e108724. https://doi.org/10.1371/journal.pone.0108724

28. Wester KL, Ivers N, Villalba JA, Trepal HC, Henson R. The relationship between nonsuicidal self-injury and suicidal ideation. J Couns Dev. 2016;94(1):3-12. https://doi.org/10.1002/jcad.12057

29. Joiner TE. Why people die by suicide. Cambridge, MA: Harvard University Press; 2005.

30. Machado RP, Zago KSA, Mendes-Rodrigues C, Calderari ES, Ramos DASM, Gomes FA. Risk factors for suicidal ideation among university students assisted by a student health care services. SMAD Rev Eletron Saude Mental Alcool Drog. 2020;16(4):23-3. https://doi.org/10.11606/ issn.1806-6976.smad.2020.169186

31. Lamis DA, Ballard ED, Patel AB. Loneliness and suicidal ideation in drug-using college students. Suicide Life Threat Behavr. 2014;44(6):62940. https://doi.org/10.1111/sltb.12095

32. Oyekcin DG, Sahinb EM, Aldemirc E. Mental health, suicidality and hopelessness among university students in Turkey. Asian J Psychiatr. 2017;29:185-9. https://doi.org/10.1016/j.ajp.2017.06.007

33. Dumith SC, Demenech LM, Carpena MX, Nomiyama S, Neiva-Silva L, Mola CL. Suicidal thought in southern Brazil: who are the most susceptible? J Affect Disord. 2020;260:610-6. https://doi.org/10.1016/j.jad.2019.09.046

34. Shadick R, Dagirmanjian FB, Barbot B. Suicide risk among college student: the intersection of sexual orientation and race. Crisis. 2015;36(6):416-23. https://doi.org/10.1027/0227-5910/a000340

35. Harrod CS, Goss CW, Stallones L, DiGuiseppi C. Interventions for primary prevention of suicide in university and other post-secondary educational settings. Cochrane Database Syst Rev. 2014;(10). https://doi.org/10.1002/14651858.CD009439.pub2

36. Fontão MC, Rodrigues J, Lino MM, Lino MM, Kempfer SS. Nursing care to people admitted in emergency for attempted suicide. Rev Bras Enferm. 2018;71(suppl 5):2199-205. http://doi.org/10.1590/0034-7167-2017-0219 